\title{
Management Presumptions and Possibilities of Human Resources Formation
}

\author{
Rūta ADAMONIENE் $\dot{1}^{1}$
}

${ }^{1}$ Department of Humanities, Faculty of Public Security, Mykolas Romeris University, Address: V. Putvinskio str. 70, LT-44211 Kaunas, Lithuania

E-mails: ${ }^{1}$ rutadam@mruni.eu

\begin{abstract}
Scientific researches were carried out when deepening into the problems connected with the fields of human resources and their formation, possibilities and activity perspectives. The aim of these researches was to clear out management presumptions of human resources formation influencing regularity and entrepreneurship orientated towards up-to-date problems as well as to present their formation possibilities. In the article the object of the research was analysed at both general and organizational levels. Following the results of the carried out researches, management presumptions of human resources formations were grounded, the characteristic of the competences of the alternation, as one of the processes in the processes of the development and progress of system elements, was presented in the article. The systematic approach towards entrepreneurship as well as towards the groups of factors influencing it (from the management viewpoint) was emphasized in the article. The further directions of the researches of human resources formation were directed in the article.
\end{abstract}

\section{KEY WORDS: Human resources, Regularity, Entreprerneurship, Competence}

\section{Introduction}

Considering globalization processes under conditions of society transformation, managerial theoretical and practical provisions of requirements for entrepreneurship and professionalism, which form human resources are brought up-todate. In a constantly changing environment, the necessity arises for constant researches of these problems and deepening into the level of the problem's investigation by searching for new decisions' measures and ways.

In the interface of millennia, under rapid progress of science and technologies and emergence of new possibilities and perspectives of social and economic development, today's period of our generation is characterized by expressions of radical changes and obliges to realize development strategy as essential human activity process, unity of nature's and human activity's worlds and necessity of complexity in society's development and progress (Melnikas, 2012).

Intellectual resources become the main source of business subject's stable competitive advantages formation, increase of their potential market value and satisfaction of dynamically developing users' needs. Thus, knowledge become an intellectual resource or active of any business subject or organization, which requires for highlighting of consistency of their functioning, systemic assessment of interaction with other economic factors, economic attitude, spread and efficient use. The problem of management of intellectual resources is one of the newest fields of management theory, and it is given a lot of attention worldwide and, first of all, in the western countries (Brooking, 1996; Sveiby, 1987; Strassman, 1998; Stewart, 2003; Edvinson, 2002). However, until recently, in scientific community there is no united opinion in examining the concepts, structure, most significant factors of intellectual resources, ways and measures of their management.

Insufficient level of knowledge and knowing for efficient management of organization describes the main presumption of human resource formation. Possibilities of human resource formation reveal how to develop that level and make human resource management more efficient: the use of intellectual resource management and knowledge/knowing; research and analysis in the process of individual's competence education by forming and developing the systems of training oriented towards development of competence; assessment of qualified counseling by determining the need for education, using career development modelling methodologies to tackle them. Thus, scientific problem of this article is insufficiently revealed human resource managerial formation presumptions and possibilities as well as their management.

Present time could be described as a society of knowledge and organizations. In economic sense, knowledge is valuable only in so far as it is realized by creating a new value and performing a certain purposeful activity. According to H.V. Perimutter (1997), any organization in becoming of global civilisation, which is professing to become competitive in global market, must orient its activity towards a global problem and to develop three main managerial abilities in paradigm of change: thinking of global civilisation, literacy of global business, competencies of conventionalism mastering.

Considering assessments of modern situation and possible perspectives, the presumption is done that human resources are formed, in perception of systemic attitude, by activity organization (entrepreneurship) and professionalism education in mankind's development and change of processes of progress evolution. 
The object of the researches analysed in the article: aspects of human resource formation professionalism and entrepreneurship, goal: to highlight managerial presumptions of human resource formation affecting professionalism and entrepreneurship oriented towards modern problems and present possibilities of their formation. Research methods used: scientific literature analysis, systemic, logical analysis and synthesis, summarizing, induction and deduction.

\section{Essence of Human Resource Formation}

Human resource formation is related to activity of various presumptions. The main presumptions are managerial, economic and social ones. Human resources are individual and collective knowledge, skills, talents, professional competencies, abilities, psychosocial state (e.g., commitment, motivation) of the people working in the organization, learning of employees, creativity, novelty, power to create additional value to a customer. And the ones influencing efficiency of organizational activity with certain competencies (creative abilities, leadership, entrepreneurial and management skills, knowledge, organizational abilities etc.) by decision making and realization. Human activity is one of the main factors of production, however, it is not the only - natural resources and capital are also important in product's production (Martinkus, Sakalas, 2003). It is important to identify weak and strong sides of human resource potential and to understand how it enables organization to act spectacularly and gain an advantage against its competitors.

The basis of intellectual resources consists of knowledge that form the biggest part of additional value created by society, and intellectualization of the used technologies guarantees a strong growth of productivity. Intellectual resources can be perceived as a good and possibility of knowledge availability and use in market's area usually depends on the fact if knowledge is a value of public or private property.

Human resources have to be perceived as organization's employees with particular competencies who influence efficiency of organizational activity by decision making and realization. Significance of human resources, that now got the name human capital, that reveals another aspect, constantly increases. In order to ensure efficiency of use of human resource, there should be created an organizational culture based on declared organizational values that would be acceptable to all employees. It is important to identify weak and strong sides of human resource potential and to understand how it enables organization to act spectacularly and gain an advantage against its competitors.

Human resources, i.e. people, unlike so called technological miracles, have a genetic, not a constructed - artificial, programmed - intellect, mind. They consciously, not mechanically react to managerial decisions: tasks, orders, instructions. These managerial instruments can stimulate enthusiasm for ones and have a suppressing effect on others. Manager using these resources must take into account intellect, temperament, character, instantaneous emotional state. They have a possibility for constant development, adaptation to technological, administrative and other changes taking place and implementation of the tasks determined by the latter. Naturally, that also depends on human's personal goals, strategy and policy of human education characteristic to the organization (Jančauskas, 2006).

All named elements and features of human resources in scientific researches are used in the context of knowledge society formation.

In modern world, change became a normal and constant phenomenon and transformations taking place in society can be considered an essential condition of global development and progress. The word "transformation" is associated with changes, therefore, while applying this concept to society as a social system according to B.Melnikas (2012), social transformations should be treated as quantitative and qualitative changes determining formation of society's life style substantially new, future or characterized by new qualitative level. In order to implement reforms successfully, not only a systemic approach is important. Knowing has a significant meaning - what needs to be changed and foreseen, how it should be done, to foresee change (reform) strategies.

P.Dalin (2001) considers change as adaptation and education. Perhaps, a training as organization of change could be measured most significantly by five disciplines of learning organization presented by P.Senge (1990): Creation of general vision as managerial problem; Systemic thinking as problems of scientific researches and counseling; General (made) thinking models as formation problems; Training by team/in team as methodological problems; Personal mastership as problem of responsibility.

Therefore, strategy of change during formation of human resources in entrepreneurship and professionalism aspect should be characterized by characteristics of active position, overcoming of limitations, sustainability through systemic approach and formation of this attitude. Thus, human resources can be looked twofold: first, as already existing ones that could be distinguished, studied and described - direction of cognition, second, as the ones under creation, formation direction of action, and, in current situation, this is a necessary condition for formation of human resources in education of competencies of professionalism and entrepreneurship (Adamonienè, 2005).

\section{Systemic Attitude Towards Entrepreneurship in Managerial Aspect}

In the area of human's mental activity, mind, there exist two directions of research of objects, phenomena or processes - analysis and synthesis. By analysing there is a striving to understand essence, structure of the analysed object, phenomenon and to look for answers to questions - of what elements the object consists, what is its structure, what are internal relations and links, what are characteristics of the object and its constituents, how they could be changed towards desired direction, etc. Synthesis is expressed in striving to connect individual components into one totality, to analyse the object, phenomenon not in isolation, but in relation with external environment in which it exists and functions. During coordination of analysis and synthesis, systemic attitude is very significant - an ability to see and cover objects not only by highlighting their internal structure, but also by assessing it in the environmental context. During this particular time 
there show up two directions and their synthesis: the first, related to social sciences (state and law theory, sociology and social psychology, history), the second is related to expansion of practical intellect (in areas of policy, administrative law, big industry mass production formation). The process of this synthesis has managed to fuse two types of activity: research (objective-ontologic) and design (organizational) which existed before, however their activity results transformed independently from each other.

With regard to development of management science, starting with period of A.Smith (according to Simon H.A., 1947) and focusing on the main studies of fundamental science on strategic management by A.D.Chandler (1962), H.I. Ansoff (1965), K.Andrews (1965), according to R.Jucevičius (1998), it can be noted that management is concurrently related to economic organizational theories or economic organization forms. By that a presumption should be done that change of activity conditions, which determines necessity of strategic management or mankind development and progress, influences entrepreneurship as reproduction of human lifestyle conditions.

In scientific literature, entrepreneurship is analysed in two main aspects. On the one hand, scientists describe entrepreneurship differently: some state that entrepreneurship is an incentive, others state that it is inborn and acquired human characteristics that allow him to think innovatively and act actively and risk. On the other hand, despite entrepreneurship is often perceived as expression of human characteristics and abilities in activity, external factors stimulating the entrepreneurship are not less important.

Summarizing, there can be distinguished two main groups of factors determining entrepreneurship: internal and external factors. Internal factors determining the entrepreneurship are related to employee's personal characteristics (activity, responsibility, persistence, determination, diligence, economy, activity, self-reliance, self-expression, factor of communication, tendency for novelties, susceptibility to information, self-motivation, cooperation, organizational abilities, ability to manage, etc.), motivation to take business (striving to be independent, desire to show own abilities, to create own work place, to implement own idea, need for self-expression, etc.), with knowledge and abilities available. External factors are related with certain environment: political, social, legal, economic, technological. These environments influence business and determine its changes. At the same time business affects environments and determines their change (Adamonienè, 2008).

Presumption is done that change of activity conditions which determines necessity of strategic management or mankind development and progress is ensured by entrepreneurship as reproduction of human lifestyle conditions, and mind development as substantial result of society's development and progress forms managerial (socio-technical) activity that enables differentiation (specialization in segments) of managerial competencies in human resource formation.

\section{Entrepreneurial Segments of Human Resource Formation}

Literature analysis and studies of management theories and concepts created a possibility to distinguish and to formulate for this case four entrepreneurial segments of human resource formation.

The formulation of the first entrepreneurial segment was enabled by studies of modern management science theories and concepts to which there should be ascribed „The Guru Guide: The Best Ideas of the Top Management Thinkers“ (1998), which presents managerial factors, mega-skills, principles, characteristics, values and truth (studies of W.Bennis, B.Nanus, J,O`Toole, S.Covey according to Boyett J.H., 1998); names the main managerial concepts and strategies of organizational activity (studies of A.M.Brandenburger, P.Drucker, G.P.Hamel, H.Minzberg, J.F.Moore, M.E.Porter according to Boyett J.H., 1998); distinguishes the main processes influencing organizational change and prospects (studies of W.A.Pasmore, R.Jacobs, J.Kotter, D.Conner, P. Strebel, P.Barwise according to Boyett J.H., 1998). The first entrepreneurial segment presents management factors, mega-skills, principles, characteristics, values and truth; names the main managerial concepts and strategies of organizational activity; distinguishes the main processes influencing organizational change and prospects. This is an entrepreneurial segment of execution, oriented towards conceptual knowledge you must know, you must know how to use them as principle rules and requirements, and without which any action is impossible. It should be ascribed to speciality knowledge and proficiency that have to be repeated and renewed constantly.

Distinguishing of the second entrepreneurial segment such as managerial skills, abilities, knowing how to orient in changing environment and act according to situation was enabled by studies of modern management science theories and concepts orienting towards modern global situation, socio-political context, international economy and competitiveness, updating globalization and multinational corporations, international financial market, strategic management of changes in undefined future world. These are the scientific studies of A.Reis, J.Traut, P.Senge, T.W.Dunfee, J.Mahoney, S.Garelli, P.Strebel, P.Barwise, J.D.Wood, S.J.Kobrin, which, in the context of professionalism and entrepreneurship for human resource formation, are raising the necessity of managerial qualifications and competencies for execution (working skills and abilities), organization (abilities and knowing how to organize employment and occupation), counseling (knowing and ability to execute future activity), i.e. upgrade the direction of organization activity in order to ensure functionality of activity. This is ascribed to a practice of professional activity.

To the third entrepreneurial segment of human resource formation there is ascribed the activity based on innovation, formation of new attitude, future creation oriented towards strategy of change paradigm. These are fundamental scientific studies of P.Drucker (1964, 1985, 1993), J.Naisbitt (1995), R.M.Kanter (1995), S.Dombergs (1998), A.Tiwana (2002), Watermann R. H. (1988) that brings up-to-date the concept of educated human, importance of new knowledge creation, value of mentality formation. This is prescribed to "marginalization" - overcoming of traditionalism, disability, inaptitude, limitation of unknowing (Adamonienè, 2005, 2007, 2013). 


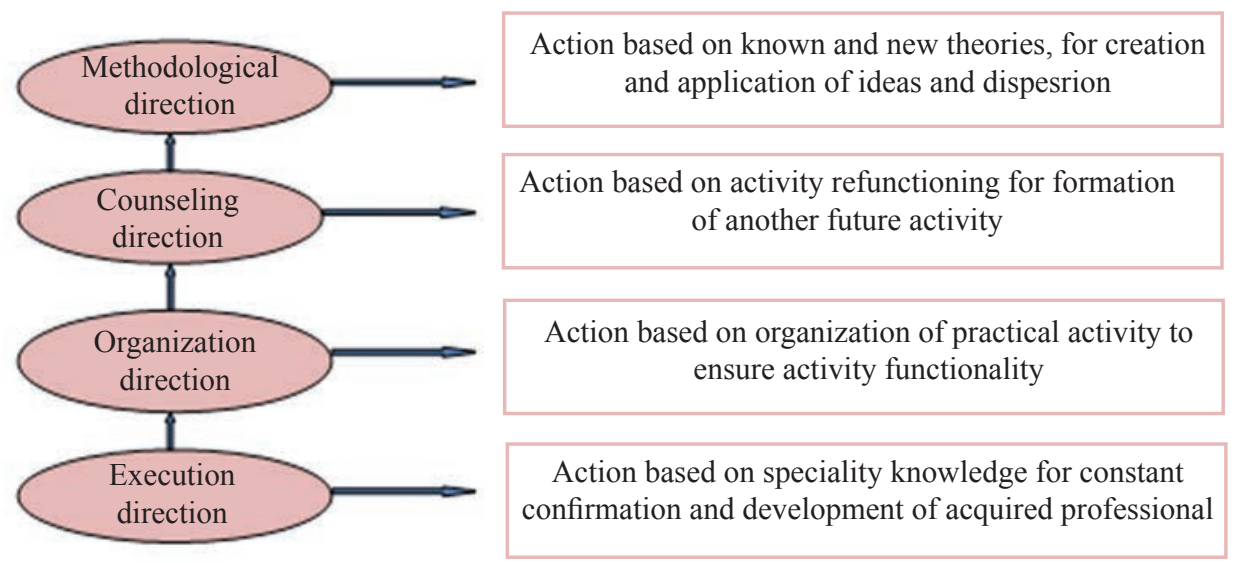

Fig. 1. Entrepreneurial segments of human resource formation

The fourth entrepreneurial segment is based on creation of ideas, dispersion, search for new methods, tools for creation of new knowledge. Therefore, methodological problem becomes more topical today (1 figure).

Thus, based on that, there was created a theoretical human resource formation model in managerial aspect ( 2 figure), which presents the processes directly taking place in change and formation of future (from direction of increase of cognition to activity efficiency).

Keeping in mind society's transformations in policy, economy, technologies, information and social fields and uncertainty of the future, human resource factors become one of the most significant. On the other hand, we become participants of modern society change - "economic human" and a phrase "we know what he wants" give the place to "mosaic human" and a phrase "nothing needs to be changed, it needs only a different thinking and the world will change".

In point of view of management strategy, purpose of organization of change, in aspect of human resource formation, is education of entrepreneurship and activeness, not only to organize or to be organized by others, but growing of knowledge, abilities and powers in order to organize occupation and realize the idea where strategic is not change itself but organization of change and its management. In other words, strategic is what is "doing" but not "what is done".

Interest in the problem of intellectual resource management is related to the sixties of the last century when postindustrial society started forming in the most developed countries of the world.

Economic activity has always been based on knowledge. Knowledge, energy resources and organization are the primal factors people used in the past and take care of them now. Production technology is nothing else than knowledgebased activity of human groups and individuals. On the other hand, the resources provided by the nature depend on knowledge. Thus, gathering, transferring and enriching of knowledge become a focus of society's progress.

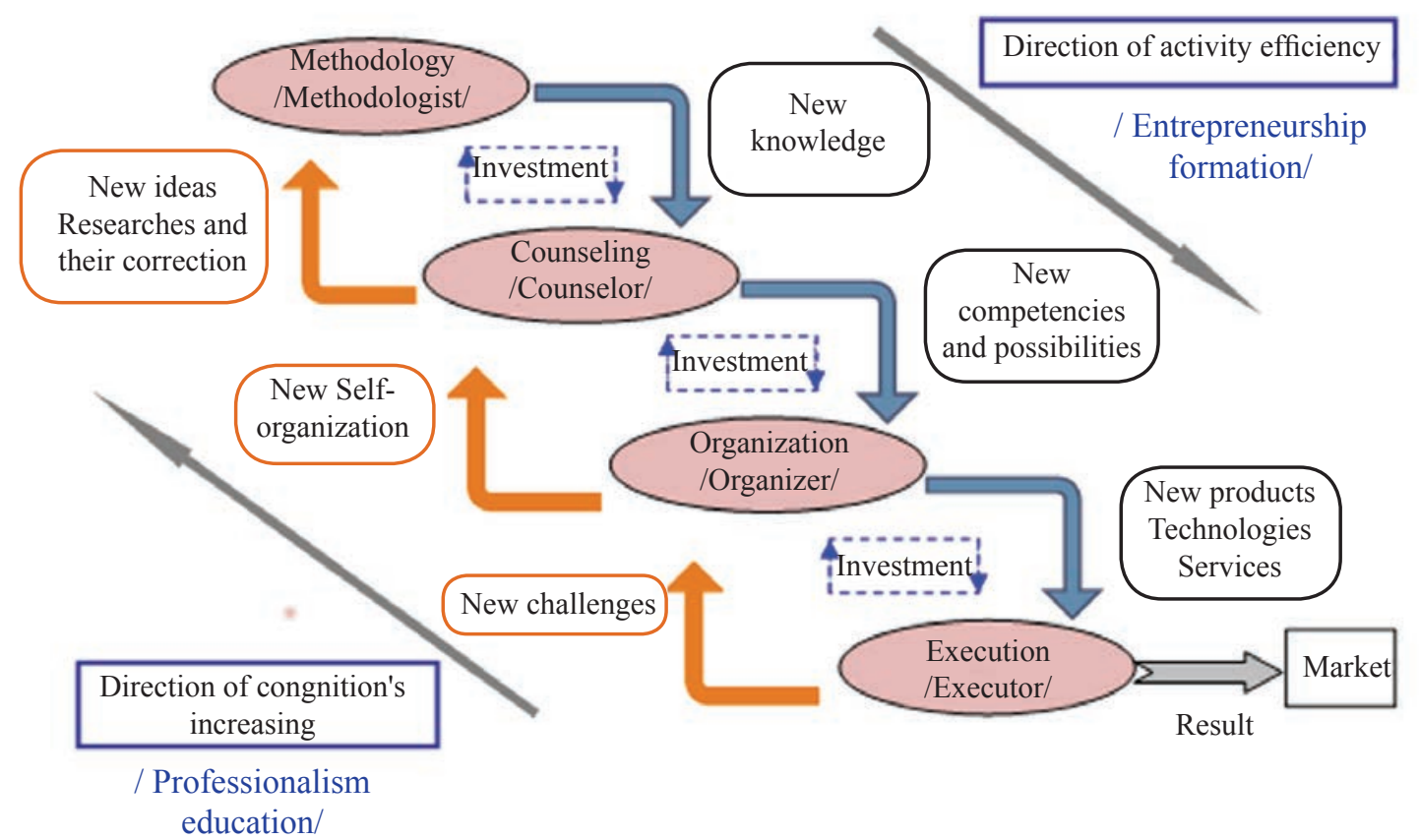

Fig. 2. Model of human resource formation in managerial aspect 
Knowledge economy society is characterized by few distinguishing features. First, knowledge directed towards products and services forms a big part of additional value created by society. This can be explained by the fact that intellectualization of the used technologies guaranties strong growth of productivity. Another feature - susceptibility of goods and services to scientific knowledge grows systematically. Besides, the market is literally dominated by intellectual goods and services. Intellectual products and services are taking more and more solid positions in the international markets. Due to the mentioned phenomena, production, protection, recycling and use of intellectual resources in knowledge-based economy obtain a substantial meaning and significance. Special role in this activity field falls on education, nature and importance of which are changing most of all.

Having summarized presented facts, there is a possibility to indicate qualitative peculiarities of knowledge economy that describe it as a way of society's advanced production (Klimov, 2000; Milner, 2003). One of the peculiarities - pace and scale of scientific technical progress are so notable that modern material production base and quality of labour resources do not correspond the progress possibilities. Another peculiarity - growth of transactions costs related to information search, market research, contracting and control of contracts' execution, protection of property rights etc., which can be assessed as a result of increasing competitiveness. Another characteristic of knowledge economy is a highly increased role of intellectual resource management.

While analysing intellectual resources in the context of economic activity, we are facing two living contradictory attitudes. On the one hand, knowledge, abilities and other components of intellectual resources are similar to all known production factors. Second, it can be indicated that such resources are a special, distinguishing potential of economic activity. Besides, there is an opinion that functioning of intellectual resources directly contradicts the main principles of economics.

Considering that such opinion is correct that would mean that knowledge cannot be treated as object of economic and market relationship. Therefore, knowledge is emphasized as economic value as well.

Knowledge is not for sale directly, but goods and services are being purchased and sold, and, which is the most important, decisions taken are based on knowledge available. Usefulness of the latter to customer depends on the value of decisions. It can be stated that situation of information that is as if working intellectual resource is different. Information based decisions are taken independently by using information together with knowledge available. However, in this case as well, there also is no preliminary valuable information available. The degree of value of the latter depends on the level of decisions taken on its basis. It is obvious that knowledge value is determined by the value of decisions available. While managing business processes, decisions can be changed, however, knowledge can't be changed (Adamonienè, 2005, 2007, 2013).

Principle of limitations of goodies states that any value characterized by usefulness is involved into the system of economic relationship due to its rarity in comparison to society's demand for it. However, it is clear that this provision is not inherent to knowledge as economic resource. It is considered that principal difference between different kinds of resources and knowledge is forming because of the excess of the latter (Stewart, 2003). Thus, value of knowledge as a resource is determined according to availability by applying it to tackle the problems, and not only the intellectual, but, first of all, economic, social, technical or behavioural ones.

Researchers many times tried to justify analysed categories of information and knowledge. One of them is R.Ackof (1972), a well-known expert of systemic research field, who proposed the use of human consciousness content analysis scheme that is being adapted and, in the recent period, consists of five concepts. It is obvious that every primal concept is a stimulus, or some kind of source for further new quality concept to appear. R.Ackoff indicates that first four components are related to the past, that means, to what was and is known, and the fifth - wisdom - is directed towards the future. Later in the literature on knowledge management, the scheme proposed by R.Ackof was modified (Bellinger, 1997), by composing it of four components: Data - Information - Knowledge - Wisdom, and it was named DIKW.

Data is a fixed but not arranged symbols, single primal facts on observed real objects, processes, phenomena, particular human activity, treated independently in any context. Usually data is grouped, differently summarized, rearranged by giving a content of information to it. Data directly has no big value, however, it is convenient to be kept in one or another form. In the processes of individual decision making, data sometimes is used directly.

Information is understood as a fixed and processed data that, during the process of thinking and understanding, is given a meaning and goal, i.e. prepared for further use. In other words, any striving to interpret, make presumptions, foresee content, i.e. gives a particular context, turns data into information. It has higher value than data as it is used for assessment of real situation, decision making. However, information is defined insufficiently and could be differently understood by subjects and explained ambiguously.

Knowledge is a determining of tendencies or substantial relations between phenomena presented in information. It is kept in people's minds and is very valuable, because, based on it, there are created new ideas, events interpreted. Unlike information, knowledge itself creates the context and can be guidelines of particular management decisions and factors. Knowledge management is sophisticated because knowledge is a product of human mind nature, it is invisible and unmeasurable and its use and transfer to other individuals depend on motivation of the transferring person. Knowledge has no value if it is not used for achievement of practical and useful goals.

Understanding expresses a regularity existing in most scattered knowledge, which gives an answer to the question "Why?" Understanding in DIKW model has not gone anywhere and became one of the coordinate axes determining knowledge vector, the second measurement is independence from the context.

Wisdom. In this stage of knowledge vector formation, there take place a summarizing of information and knowledge and highlighting of their systemic principles and regularities in point of view of the past and the present. Moving towards 
knowledge vector from data to wisdom is not a mechanical summing up of information and knowledge. Rather it is assessed understanding of regularities in point of view of the civilisations' past and present. Sometimes, wisdom forces to keep under cover till a corresponding time the knowledge that society is morally unprepared to use.

In scientific literature there are known other knowledge management models that help to determine stages of knowledge formation. One of them was proposed by T.Durand (1996), who raised experience to a much higher grade - content of competence. In this case, knowledge is created gradually by information accumulating and turning into a system of attitudes that provides consistency and structure to a gathered base of knowledge. Information is not only a simple data. This is data that has been recognized, selected for processing and adapted for a corresponding structure of knowledge. On the other hand, experience has to be interpreted as a higher grade of knowledge which covers a level of competence. Experience is not only prescribed to the level of substantially progressed competence, requires not only a coordination of knowledge and knowing, but also an ability to understand, explain, act in the field of competence. In certain points the experience exceeds the competence due to a substantial jump in the level of competence and re-combination and merging of various elements of competence. In other words, there exists such sequence of stages of knowledge change that leads from data and information to knowledge and experience.

Intellectual resources became the main source of acquiring of stable competitive advantages for business organizations of any type, increase of their potential value and satisfaction of dynamically developing needs of customers.

Under market economy conditions, value of people's work, value of products and services realized by enterprises depend on used information and knowledge. Therefore, organizations must learn to manage intellectual resources because they became the main resource of economic activity and their efficiency in point of view of use became the framework factor allowing to determine market's demands and to satisfy them in innovative way (Adamoniené, 2005, 2007, 2013).

All innovative processes are being managed by a human who is considered to be the main element in modern organization. Most changes in labour market that were analysed by management scientists Greenhaus H.J., Goldshalh M.V., Hartung J., Drucker P., V.W.Cascio require human's ability to act in a changing situation by taking responsibility for the tasks delegated to him. The same responsibility comes for own career. Under market conditions, everyone has to take care of own qualification and its development and show an initiative: to select and keep or create a prospective working activity that corresponds abilities and helps to realize themselves in full and to ensure material security. Human's wishes, needs, goals, interests are reflected in his career in formation of which there participate both the organization and he himself. Career, as activity of the organization and the human, is influenced by various factors and environmental changes.

Career theory is often analysed in cultural aspect by assessing differences of individuals. Each individual is different and unique. Differences of individuals are expressed through their abilities, needs, goals and interests. Meanwhile, abilities and interests are affected by constantly changing environment and such factors as social status, gender or dependence to some ethnic group. It is considered that future working society will be older, the number of working women will increase. Drucker P. states that one of the most striking characteristics is a strong decrease of birth rates in developed countries and at the same time increase of elderly people.

There are distinguished few reasons due to which career concept remains and ideas of its progress inside organization or another activity expand. One of them, career, is dynamic in time. This enables individuals to assess their abilities. Individual can asses his working life by interpreting the past in the context of present situation. Thus, they can correct their future goals. Career concept still can be used in organization. In order the organization to be able to achieve its goals, activity advantage, it needs to strive for full use of employees' potential.

Changing work structure and content require for new skills and abilities, the need for employees of higher competence shows up, however, due to the same reason the existing works and the employees performing that work are being eliminated. Another aspect of increasing technological level - employee only services and maintains modern technological equipment; increased demand for highly qualified employees; employees' without high qualification supply - demand balance is changing.

High competitiveness and market globalization have impact on changes inside organizational structure. H.J.Greenhaus states that bureaucratic organizations characterized by stability and certainty will be changed with organizations of new structure possessing the same characteristics: a small number of the main employees (remaining contingent consists of part time employees and employees working according to the specific temporary contracts); flat hierarchy with selfgovernment groups responsible for main organizational activities; rapid integration of new technologies to work process; intense creation of alliances with internal and external partners.

Environment of high competitiveness requires for high level of flexibility from the organizations. And that, according to H.J.Greenhaus, creates presumptions for organizations to use short time transaction contracts. Employees are expecting the flexibility in respect to new structure job and a development of new skills depending on organizational need. Organization, in turn, is not committed to the employee by long term employment, however, it creates possibilities for career, i.e. further professional growth and development. That determines changes towards employees' career attitude and formation.

Career, its management was analysed by many Lithuanian (A.Sakalas, A.Šalčius, Petkevičiūtè N., A.Valackienė, V.Stanišauskienė) and foreign authors (H.J.Greenhaus, M.V.Goldshalh, P. Drucker, M.Segalla, D.Rouzies, M.Flory et al.). A human spends a significant part of his life in organization (in the course of working activity). Relationship of employee and organization and striving for their mutual benefit is best illustrated by the statement of J.W.Newstrom: "organization needs employees to achieve enterprises goals, and employees need organization to realize their human goals, needs and interests".

Foreign literature analyses career in two approaches: career as a structural achievement of profession or organization 
and career as an individual achievement. Career as a structural achievement of profession or organization. This attitude is illustrated by a presented career as a sequence of particular positions or "ideal" profession of a practitioner. Career can also look like a climbing ,stair“ in a particular organization. Career is an individual achievement. Everyone gathers unique part of work, position and experience, and that determines different career of each person. Thus, individuals have to understand what type of career they want to achieve and to strive for it by taking certain decisions.

Most employees do not analyse their abilities and career goals not because they don't want but because they pay no attention enough to that. It is an organization that should stimulate self-assessment and to create conditions for that. During counseling conversation, an individual can reveal his preferences and assess own possibilities. At the same time, it is purposeful to find out personal problems because they determine individual's career aspirations. While foreseeing real career goals, individual needs to know its possibilities and boundaries in the organization. For that purpose, the organization has to familiarize employees with forecasts of demand, to inform constantly on new jobs (Greenhaus, 2000).

In modern society, there efficiently work the organizations which are running such policy as rational work regime, space creation for initiative and creativity, give a priority for own employees for career or follow the principle that employee looks for job but not vice versa. In this case, every employee is an activity partner. Professional career, its real ensuring is a particularly vital, spontaneous, originating from human nature source of activation of staff members, their initiative. Career management application in organization helps to use efficiently employees' possibilities, increase confidence in own skills, ensure constant increase of number of qualified professionals, satisfy the needs for development of employees' potential and professional growth.

Global practice indicates that human is preparing for career in a pre-school age already. There exist integral structures of preparation for career, which bring together education institutions, the government, trade unions and employers. Efficient organizations are interested in professional growth of all employees, take care of their career and offer different programmes of its planning. And that gives a tangible benefit both to employees and the organization, because career planning allows to relate the plans of employees' professional growth with organizational tasks. When career of individual employees is directly related to organization, they are more interested in the problems, participate their tackling, are interested in success of the whole organization. In this case employees are caring themselves about their qualification refreshment, professional knowledge deepening and renewing, higher use of own possibilities. This is evidenced by the fact that professional career begins with the human's birth and plays a big role during human's entire conscious life.

During different changes, big emotional and economical transformations are being experienced, there are changing entire fields of human life between which there distinguishes a change of working world. New changed conditions of the present are direct challenge for an individual because they are reflecting in human's activity and behaviour. People's working life, professional career models are changing as well. Specifics of career as a research object requires to examine organization and employee together. Organization and employee affect each other in the context of working environment. Organizational development affects career changes, changes of individuals lead to organizational changes. Interaction of employee and organization is based on striving to satisfy mutual needs.

In foreign literature, the model of incentive-contribution proposed by B.Barnar and R.Simon long time ago could be found. The essence of this model - individual results of organization's incentives applied to persons and that of person's contribution to organization have to be satisfying in order relationship between person and organizations would be efficient and constant. Thus, a correspondence of personal and organizational needs shows up. Incentive-contribution model directly integrates into the model of modern career, where career formation is based on coordination of personal and organizational interests.

Summarizing possibilities of career development, in aspect of incentive - contribution, it can be stated that organizations offer incentives to employees in efforts to satisfy personal needs, and persons offer own behaviour in efforts to give some contribution to the organization. As the authors of incentive-contribution model state, organizational needs arise from interaction of its individual members. A more precise argument from a similar start position sees the organizations that have three important main activities: adapting to external environment, striving for goals and internal self-supervision. One of the most important modern career needs is a need for development. In the case organization does not respond the need for development, it is likely the work tools will be not corresponding. The need for protection will be satisfied when organization gives a third opportunity. Thus, organization has to please a person's need to keep the career, and also to allow the person to assist less experienced colleagues.

In modern career, organization takes no responsibility for employee's career. However, in some cases organization, being responsible for people's career needs, has an opportunity to benefit from the general level of commitment. Performed career researches in theoretical point of view revealed the main aspects of career concept by assessing working environment changes and their impact on organization, its employees and career formation. Lithuanian economic and social situation is specific and therefore we are interested in dominating attitude towards career, career needs and possibilities. During the research there was a striving to determine: importance of career planning; what are the needs for development and what employees expect from the organization; how organization helps new employees to adapt in the organization; what special attention is given to new organization members. Based on the research results, it was determined that leaders of organizations are giving insufficient attention to the process of career planning, employees wishes and needs are taken into account insufficiently, no special attention is given to new employees and possibilities to refresh qualification and career progress are introduced insufficiently because organization's efficiency also depends on the fact if employees satisfy their expectations, if their goals meet the goals of the organization and if execution of tasks is successful. And for employees, it is very important to know about the possibilities to realize own goals and expectations, refresh qualification, satisfy needs in the organization. 


\section{Further Directions of Human Resource Formation Researches}

The changes taking place, available input and performed researches suppose the main directions of development of scientific researches performed and under performance.

According to the statements of modern theoreticians, known and applied theories and concepts have no necessary tools and methods for work with a becoming object. That means that while creating "new" knowledge by using "old" tools and methods, we simply are continuing the past. This is also confirmed by the statement of P.Drucker (1993) - "the being is formed from the future". That means that ontological and methodological problems are becoming more and more topical today. Therefore, there are requirements for human resource formation for new logics of thinking and activity, search for new channels of dispersion (translation), intellectual resource management and use of new knowledge/know how.

In organizations, human intellect is considered the main capital of the enterprise. Quality of provided services and successful activity of organization depend on employees' qualification and available competence. All that poses new requirements to both the employee and his work. Tackling of any new problem, ability to apply available knowledge in a particular crisis situation, execution of qualitative work requires for a corresponding competence of employee. Therefore, it is necessary to research and analyse individual's competences in the education process in order to determine existing peculiarities of teaching/learning systems, different methods of education - formal and informal - and looking for new methods, forming and developing systems of training oriented towards competence education.

Competence - human's expression in activity. By acquiring profession, human acquires only a certain qualification that includes primal skills in that professional activity. He demonstrates and develops his competence later - by executing and developing his professional activity, striving for both horizontal and vertical professional career. The goal of constant need for learning should be - a condition of keeping of interesting job in a changing society and career possibility, with regard to the aspects of human nature, because employee's attitude towards modern job he chose, work style and impact of his personal characteristics on work are very important to employer. Modern Lithuania is lacking information library that would assist human to know and develop himself, to strive for a targeted professional career according to his intellect and efforts. It is natural, that in every stage of life human faces many questions that are not receiving qualified answers. Therefore, importance of qualified counseling is huge today. Counseling goals and methods are determined by different theories that the counselor must know. Counseling and its impact are known for a long time, its methods and measures are rapidly changing and developing, however, due to its insufficient scientific assessment there still are some uncertainties. Career counseling is a special activity providing assistance for the client while tackling the problems of individual employment by assessing his inner characteristics and labour market situation. These problems are related to selection of profession, determining of profile of vocational education, employment and change of professional activity field. For most clients of employment services, the search for socialization problem tackling is topical as well. Therefore, while examining these problems, it is topical to analyse motivation of employees' career creation, assess motivation of professional activity, determine the need for learning by qualification refreshment, stages of career creation, by using methodologies of career development modelling to tackle their decisions.

\section{Conclusions}

Change, as one of the elements of evolution processes system in processes of mankind development and progress, should be initiated by formation of systemic attitude and active work method. Formation of systemic attitude, dual principle, in modern situation, is a necessary condition while forming human resources oriented towards strategy of change paradigm, novelty, formation of new attitude, concept of the educated person.

Mankind development and progress, as reproduction of human living conditions, is ensured by development of professionalism and entrepreneurship competencies. Managerial presumptions of human resource formation in the aspect of professionalism and entrepreneurship are differentiated by specialization segments: direction of execution action based on speciality knowledge for constant confirmation and development of acquired profession; direction of organization - action based on practical organization of action in order to ensure activity's functionality; direction of organization consulting - action based on re-functioning of activity for formation of another, future activity.

Intellectual resources became the main source of acquiring of stable competitive advantages for business organizations of any type, increase of their potential value and satisfaction of dynamically developing needs of customers. Knowledge management as type of managerial activity is characterized by the fact that it is a resource and expresses itself as a management object practically at all management levels and in all management functions, because there is no activity where knowledge would be not a source of development and improvement. Besides, management of the latter is directly related to use of modern informational technologies, internet and other universal networks that allow gathering and dispersion of knowledge required. Knowledge became a value that requires systemic assessment, sustainable attitude, effective dispersion and efficient use.

Environmental changes are changing not only activity of organizations, but also an attitude towards career organization and development inside the organizations. Modern organizations are creating presumptions for transformations of career formation. They must be able to assess markets, culture, employees and new management styles, and that means that the attitude is changing not only towards a work and its assessment but also towards a career that as the main mechanism allows integration of employee's needs, personal goals and expectations into a targeted organizational activity. 


\section{References}

1. Ackerman P.L., Heggestad E.D. Intelligence, personality, and interests: evidence for overlapping traits. Psychological Bulletin, 1997, 121, p. 19-45.

2. Ackoff R. L., Emery F. E. On Purpose ful Systems. 1972, Chicago and New York, Al-dine, Atherton.

3. Adamonienè R., Pilipavičius V. Influence Means Fostering Competencies of Social Entrepreneurship. Rural development 2013: the sixth international scientific conference. Kaunas: Akademija. 6 (1), p. 19-24.

4. Adamonienè R., Pilipvičius V. Presumptions of the human resources development (HRD) management. Economics and rural development: research papers, 2005, 1, p. 7-12.

5. Adamoniené R., Šilingiené V. Consultant teaching oriented towards the competence training. Changes in Social and Business Environment, November 8-9, 2007, Panevėžys, Lithuania : conference papers. Kaunas : Technologija, p. 5-9.

6. Boyatzis R. E. Core Competencies in Coaching Others. 2002, Case Western rezerve University.

7. Boyatzis R. E. The Competent Manager. 1982, New York: Wiley.

8. Boyett J. H., Boyett J. T. The Guru Guide: The Best Ideas of the Top Management Thinkers. 1998, John Willey \& Sons.

9. Brownlie D., Hewer P., Tadajewski M. Thinking ,Communities of Academic Practice': on space, enterprise and governance in marketing academia. Journal of Marketing Management, 2009, 25 (7/8), p. 635-642.

10. Collin A. Learning and Development /I. Beardwell, L. Holden. Human Resource Management: A Contemporary Perspective. 1997, London: Pitman.

11. Collin A. Managers' competence: rhetoric, reality and research // Personnel Review, 1989, 28 (6), p. 20-25.

12. Cowling K., Tomlinson P. R. Globalisation And Corporate Power. Contributions to Political Economy. 2005, 24 (1), p. 33-54.

13. Defourny J., Nyssens M. Social enterprise in Europe: At the crossroads of market, public policies and third sector. Policy and Society, 2010, 29, p. 231-242.

14. Dess G.G., Lumpkin G.T., Taylor M. L. Strategic Management. 2005, 2 ed. New York: McGraw-Hill Irwin.

15. Dickson T., Bickerstaffe G. Financial Times "Mastering Management". 1997, London Business School, FT Pitman Publishing.

16. Diochon M. C. Entrepreneurship and Community Economic Development. 2004, Montreal Quebec.: McGill-Queens University Press.

17. Domberger S. The Contracting Organization: A Strategic Guide to Outsourcing. 1998.

18. Drucker P. F. Managing the non-profit organization: practices and principles. 1990, Oxford: Butterworth-Heinemann.

19. Gliedt,T., Parker, P. Green community entrepreneurship: creative destruction in the social economy, International Journal of Social Economics, 2007, 34 (8), p. 538 - 553.

20. Greenhaus J. H. Career Management. 2000, 3ed.: Ford Worth, 491 p.

21. Haugh H., Kitson M. The Third Way and the third sector: New Labour's economic policy and the social economy. Cambridge Journal of Economics, 2007, 31 (6), p. 973-994.

22. Henry C. Entrepreneurship in the creative industries: an international perspective. 2007, Northampton Massachusetts, Edward Elgar Publishing.

23. Huggins R., Johnston S., Steffenson R. Universities, knowledge networks and regional policy. Cambridge Jnl Regions, Econ and Society, 2008, 1 (2), p. 321-340.

24. Iandoli L., Landström H. Raffa M. Entrepreneurship, competitiveness and local development: frontiers in European entrepreneurship research. 2007, Northampton Massachusetts.:Edward Elgar Publishing.

25. Yujuico E. Connecting the dots in social entrepreneurship through the capabilities approach. Socio-Economic Review, 2008, 6, p.493-513.

26. Jones P., Osterweil C., Whitehead D. Delivering Exceptional Performance. Aligning the Potential of Organizations, Teams and Individuals. 1996, London.: Pitman Publishing.

27. Kanter R.M. World Class. Thiving Locally in the Global Economy. 1995, New York.: Siman and Schuster.

28. Koteen J. Strategic Management in Public and Nonprofit Organizations: Managing Public Concerns in an Area Of Limits. 1997, New York: Praeger.

29. Melnikas B. Transformacijos. 2012, Vilnius: Vaga.

30. Mendell M. Reflections on the evolving landscape of social enterprise in North America. Policy and Society, 2010, 29, p.243-256.

31. Miles R. E., Miles G., Snow C. C. Collaborative entrepreneurship: how communities of networked firms use continuous innovation to create economic wealth. 2005, Stanford California.: Stanford University Press.

32. Naisbitt J. Global paradox. The bigger the world economy, the more powerful its smallest players. 1995.

33. Neumark D., Kolko J. Do enterprise zones create jobs? Evidence from California's enterprise zone program. Journal of Urban Economics, 2010, 68, p.1-19.

34. O'Leary D. E. Enterprise ontologies: Review and an activity theory approach. International Journal of Accounting Information Systems, 2010, 11, p. 336-352.

35. Pedler M., Aspinwall K. A Concise Guide to the Learning Organization. 1998, London.: Lemos \& Crane.

36. Peredo A. M., Chrisman J. J. Toward A Theory Of Community-Based Enterprise. Academy of Management Review, 2006, 31, p.309-328. 
37. Perlmutter H. V. Becoming Globally Civilized, Financial Times Mastering Management, Pitman Publishing in association with IMD, London Business School and Wharton Business School, Philadelphia, PA. 1997.

38. Pickering K. Alternative Economic Strategies in Low-Income Rural Communities: TANF, Labor Migration, and the Case of the Pine Ridge Indian Reservation. Rural Sociology 2000, 65, (1), p.148-167.

39. Poole D. L., Negi N. Transnational community enterprises for social welfare in global civil society. International Journal of Social Welfare, 2008, 17 (3), p. 243-246.

40. Ryan M. Human resource management and the politics of knowledge: Linking the essential knowledge base of organization to strategic decision making. Leadership \& Organization Development Journal. 1995, 16 (5) p. 3-10.

41. Robbins S.P., Judge T.A. Organizational behaviaur. 2011, (13 ${ }^{\text {th }}$ edn $)$, Upper Saddle River: Pearson.

42. Robbins S.P., Judge T.A. Organizational behavior (1 $1^{\text {th }}$ ed.). 2011, Upper Saddle River: Pearson.

43. Rothaermel F. T. Strategic Management: Concepts and Cases. 2012, McGraw-Hill: Irwin.

44. Savanevičienė A., Stukaitė D., Šilingienė V. Development of Strategic Indivudual Competences. Engineering economics. Kaunas, 2008, 3(58).

45. Schofield S. The Evolution of Government Outsourcing Policy. Contract Management. 2008, 48(6), 54-61.

46. Senge P. The fifth Discipline:The Art und Practice of the Learning Organization. 1990, New York.: Doubleday Currency.

47. Simerson K. B. (2011). Strategic Planning. A Practical Guide to Strategy Formulation and Execution. New York: Praeger.

48. Spencer L. M., Spencer S. M. Competence at Work: Models for Superior Performance. 1993, New York: John Wiley \& Sons, Inc.

49. Sutton S. G. Enterprise systems and the re-shaping of accounting systems: A call for research. International Journal of Accounting Information Systems, 2006, 7, p.1-6.

50. Tirana A. The Knowledge Management Tolkit. Orchestrating IT, Strategy and Knowledge Platforms Second edition. 2002, Prentice Hall.

51. Toft G. Synoptic (One Best Way) Approaches of Strategic Management. Handbook of Strategic Management, edited by Rabin J., Gerald J. Miller, and Hildreth W. 1998, New York: Marcel Dekker.

52. Torri M. C. Community-based Enterprises: A Promising Basis towards an Alternative Entrepreneurial Model for Sustainability Enhancing Livelihoods and Promoting Socio-economic Development in Rural India. Journal of Small Business \& Entrepreneurship, 2010, 23 (2), p. 237-248.

53. Tracey P., Phillips N., Haugh, H. Beyond Philanthropy: Community Enterprise as a Basis for Corporate Citizenship. Journal of Business Ethics, 2005, 58 (4), p. 327-344.

54. Watermann R. H. The Renewal Factor // How the Best Get and Keep the Competitive. 1988.

55. Weinert F. E. Concept of Competence: a Conceptual Clarification. In D. S. Rychen \& L. H. Salganik (Eds.), Defining and Selecting Key Competencies. 2001, Seattle: Hogrefe\&Huber Publishers, p. 45-65. 